\title{
Accounting Reform In The Republic Of Moldova
}

\author{
Jack Armitage, (Email: Jack_Armitage@unomaha.edu), University of Nebraska at Omaha \\ Mike Neider, Moldova, Chisinau \\ Marina Shelaru, Academy of Economic Studies, Moldova, Chisinau
}

\begin{abstract}
Many countries of the former Soviet Union, including Moldova, are facing the challenge of building a strong economy that will lead to long-term economic stability. Like other former Soviet States, Moldova has had to undertake a total transition from a planned economy to a market economy. Economic reform in Moldova has been a slow, painful process with high unemployment rates. During the past 10 years, Moldova has made significant economic reforms, but much is yet to be accomplished. The purpose of this paper is to examine the accounting reforms that have taken place in the Republic of Moldova since 1991, when they declared their independence from the former Soviet Union. This paper will present background information on the Republic of Moldova, and examine the objectives of accounting reform, accounting practice reforms, and accounting education reforms.
\end{abstract}

\section{Introduction}

$\mathcal{G}$ rowth of private enterprises is essential to economic development, and a vital ingredient of success is a strong accounting profession. Private enterprises contribute substantially to job creation, income generation, and economic growth. Many countries of the former Soviet Union, including Moldova, are facing the challenge of building a strong economy that will lead to long-term economic stability. Like other former Soviet States, Moldova has had to undertake a total transition from a planned economy to a market economy. The previous economic system relied on closed markets in Eastern Europe. Economic reform in Moldova has been a slow, painful process with high unemployment rates. During the past 10 years, Moldova has made significant economic reforms, but much is yet to be accomplished.

The purpose of this paper is to examine the accounting reforms that have taken place in the Republic of Moldova since 1991, when they declared their independence from the former Soviet Union. This paper will present background information on the Republic of Moldova, and examine the objectives of accounting reform, accounting practice reforms, and accounting education reforms.

\section{The Republic of Moldova}

The Republic of Moldova is located in Eastern Europe and is bordered by Romania and Ukraine. Its population is approximately 4.5 million and its land area is about 34,000 square kilometers. Moldova's largest city is Chisinau with a population of approximately 800,000. The monetary unit in Moldova is the Lei, and Moldova experienced significant inflation during the early 1990s. At some points, inflation was as high as 2,000 percent. By the late 1990s, Moldova had gotten their inflation generally under control, with inflation rates around 10 percent.

The region that now comprises Moldova was previously known as Bessarabia and was not called Moldova until 1940. The region has experienced a long history of foreign domination. Moldova gained her independence

Readers with comments or questions are encouraged to contact the authors via email. 
from the USSR in 1991, and in 1992 joined the Commonwealth of Independent States (CIS) and the United Nations. The first free elections held in Moldova occurred in 1994.

Moldova's economy dependents heavily on agriculture. There are no major mineral deposits in the area, but Moldova possesses fertile farmland and a climate favorable to agriculture. Moldova's primary exports are wine and foodstuffs.

\section{Objectives of Reform}

Moldova's success will require a strong economy, and a successful economy will require significant business reform. Therefore, that is the task before Moldova. How are they attempting to accomplish it?

Moldova's economic reforms have focused heavily on privatization of government owned assets and accounting reforms. State owned assets need to be transferred to private ownership for the economy to achieve long run success, and their accounting profession must adopt modern accounting and auditing standards to support the new private businesses.

The first privatization law was enacted in Moldova in 1991 and the privatization process began in 1992. Moldova enacted additional privatization laws throughout the decade as privatization continued. Currently 45 percent of Moldova's GDP is from private sector activities, while 60 percent of Moldova's large scale businesses have been privatized. Although Moldova is making progress in privatization, they are lagging behind most of the other countries in central and Eastern Europe.

Moldova has made significant progress in accounting and auditing reforms. With the support of the government and the Minister of Finance, Moldova has been able to quickly adopt necessary changes and it is one of the leading countries in central and Eastern Europe in accounting reforms. The importance of accounting reform can best be summarized by the following statement made by Mihail Manoli, the Minister of Finance for the Republic of Moldova at the time of his statement: "Accounting reform and the use of international standards will create favorable conditions for capital market development, investment, and the integration of Moldova into the world economy."

\section{Accounting Practice Reform}

Moldova's accounting reform has been spearheaded by the Moldovan Accounting Reform Project (MARP). MARP was funded by the U.S. Agency for International Development (USAID), and managed by EastWest Management Institute. USAID is a United States government agency that contributes to the U.S. national interest by supporting the people of developing and transitional countries in their efforts to achieve enduring economic and social progress and to participate more fully in resolving the problems of their countries and the world. Since 1992, the USAID Regional Mission to Ukraine, Belarus, and Moldova has worked with governments, nongovernmental organizations, and implementing partners to further progress of democratic development, economic restructuring, and social sector reform in the region.

MARP was managed by the East-West Management Institute (EWMI), which is a not-for-profit organization dedicated to promoting economic reform in developing and transition economies. EWMI was founded by financier and philanthropist George Soros. EWMI offers expert services to meet the needs of emerging markets and is dedicated to providing solutions to the challenges of developing economies. Some examples of EWMI's achievements include:

- $\quad$ Developed Junior Achievement programs throughout NIS middle schools and high schools

- $\quad$ Provided 3-6 month accounting training courses in the Baltic countries, Russia, Ukraine, and Moldova

- $\quad$ Sponsored enterprise restructuring in Hungary; land reform, privatization, and accounting reform in Moldova; legal and regulatory reform in Bosnia Herzegovina; and judicial training in Albania

- $\quad$ Developed computer based training programs in Russia 
MARP had three primary objectives for the accounting reforms they wanted to implement in Moldova. These were to:

- $\quad$ Provide assistance to the Government in drafting and implementing new accounting and auditing standards based on international standards

- $\quad$ Build a self-sustaining association to promote accounting and auditing principles and to train professionals

- Insure long-term professional capacity by developing new accounting and auditing curriculums with institutions of higher learning

MARP has worked to assist the Moldovan Government in their adoption of new accounting and auditing standards. Starting in 1998, Moldova began adopting National Accounting Standards, and by 2001, they have adopted 23 National Accounting Standards based on the International Accounting Standards. In 2000, the Moldovan government adopted 36 National Standards of Auditing based on International Standards of Auditing. MARP also assisted the Government with developing reforms in the national tax system and worked to help the government reconcile the financial accounting system with the tax system.

Additional work has also been done to create a self-sustaining professional association of accountants in Moldova. One area of that project has been to provide public education programs about accounting. One stumbling block is the status of an accountant in a planned central economy. The accountant's role was very clerical in nature with data being gathered primarily for control purposes, and much less so for decision making. A survey of Russian secondary school graduates rated 'accountant' as the $91^{\text {st }}$ most desirable profession out of 92 professions available (Enthovan 1999). So, MARP has not only been attempting to teach the technical accounting skills needed, but also to change the mindset of how the public views accountants.

MARP conducted numerous public educational programs. They held seminars for business managers to explain the benefits to their businesses of a well-developed accounting and auditing profession. Representatives from more than 2,000 organizations have attended these programs.

MARP also worked to support development of the Association of Professional Accountants and Auditors (ACAP). MARP achieved significant success in the development of this association. ACAP was the first professional association from a country of the former Soviet Union to be inducted into the International Association of Accountants (IFAC). IFAC Director General John Gruner stated that ACAP is the best he has ever seen from a young developing organization.

ACAP was founded in 1996 by just a few founding members. Today it has more than 1,900 members. ACAP has adopted a charter, by laws, is governed by a board of directors, and has a salaried executive director.

ACAP adopted a certification program that was developed in accordance with IFAC guidelines. Upon passing the certification exam, an individual is designated a PCA (Professional Certified Accountant). Only a small number of people (15) have currently completed the exam, but many have passed parts of the exam. There will be many more in the future as new university graduates will be better prepared to sit for the exam.

Membership in ACAP requires mandatory continuing professional education (CPE) and ACAP offers numerous CPE programs. ACAP has also adopted a code of professional ethics.

Another area where MARP worked to reform accounting was in the publication of materials. They developed four training manuals, The New Accounting System, Financial Accounting Manual, Management Accounting Techniques, and Tax Accounting. Over 17,000 copies of these manuals have been distributed.

MARP also developed an extensive training program for practicing accountants. These courses were sponsored by MARP and ACAP and offer very extensive training. Currently 50 trainers offer courses all across Moldova. Courses have included the following titles: 
- International Program in Accounting and Auditing
- The Methodology on Conversion to the New Accounting System and Preparation of the Financial
- $\quad$ Costements
- $\quad$ Audit
- $\quad$ Fow to Read Moldovan Financial Statements
- $\quad$ Accounting for Beginners
- $\quad$ Accounting for Income Tax and VAT
- Preparation of Annexes to Financial Statements
- Theparation of Financial Statement and Tax Declarations
- $\quad$ New Accounting System and the Tax Code of the Republic of Moldova

As can be seen from the titles, these courses provided a wide range of information for preparers and users of financial information.

\section{Educational Reform}

The future of the accounting and auditing profession in Moldova ultimately depends on Moldovan universities providing quality education to accounting students. MARP worked with the Moldovan Ministry of Education as well as several universities throughout Moldova to improve accounting education. Their goal is to produce graduates at approximately the U.S. CPA level of knowledge.

MARP followed an ambitious educational reform program. Curriculum reform is complex and a slow process. Since professors consider themselves experts in the areas in which they teach, they are often not readily open to suggestions for changes to their courses. Because of this reluctance on the part of professors to change, curriculum change can be a slow process.

MARP took a very intelligent approach to curriculum reform. They proposed the international education guidelines published by the International Federation of Accountants as the basis for the new accounting curriculum. Thus, the new curriculum would not be viewed as something being imposed by MARP, but instead as a curriculum that is useful throughout the world. MARP also followed the curriculum guidelines of the International Association for Management Education (AACSB). Certainly accreditation is not possible in the near term for most Moldovan universities, but by introducing the guidelines now, it can be a future goal of those universities.

MARP also felt it would be useful to follow the U.S. model of a close association between academia and the accounting profession and its professional societies. This type of cooperation is not common in countries in central and Eastern Europe. Thus, MARP has been utilizing ACAP in the educational reforms as much as possible. These links should help insure that curricula remain current and relevant since practitioners are involved in the process.

For accountants to function in the modern world, they need knowledge about their home country's and the world's social, economic, and political systems. A strong liberal arts foundation is necessary for any future accountant. Accountants also need a solid knowledge of the business environment, so general business courses must be included in the core curriculum. And finally, accountants need strong technical skills that will come from their accounting courses.

The new curriculum that has been adopted in Moldova at the Academy of Economic Studies in Moldova (AESM) is a five-year program consisting of 2,400 contact hours. An example of the new five-year curriculum is shown in Table 1. 
General education courses are required in the following areas:

$\begin{array}{ll}\text { - } & \text { Fine Arts } \\ \text { - } & \text { Humanities } \\ \text { - } & \text { Natural Sciences } \\ \text { - } & \text { Informational Technology } \\ \text { - } & \text { Multicultural Perspectives } \\ \text { - } & \text { Global Issues }\end{array}$

The business core requires study in the following eleven areas:

$\begin{array}{ll}\text { - } & \text { Mathematics } \\ \text { - } & \text { Statistics } \\ \text { - } & \text { Economics } \\ \text { - } & \text { Accounting } \\ \text { - } & \text { Management } \\ \text { - } & \text { Finance } \\ \text { - } & \text { Production Operations Management } \\ \text { - } & \text { Information Systems } \\ \text { - } & \text { International Management }\end{array}$

The required accounting courses consist of the following courses:

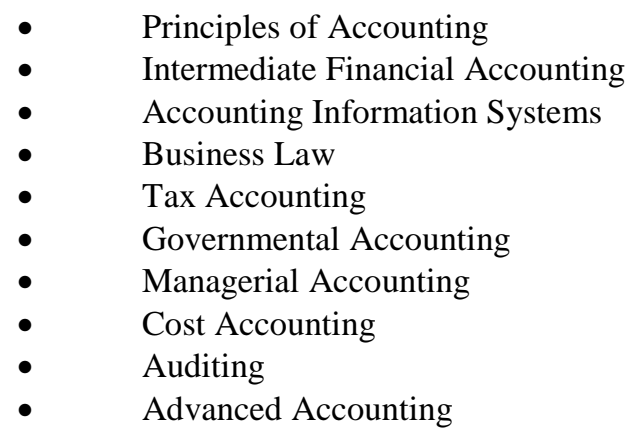

An additional direction of the accounting educational reform lead by MARP was the pairing up of a U.S. university and the Academy of Economy Studies in Moldova. The U.S. University is the University of Nebraska at Omaha (UNOmaha). This university was selected because of previous cooperation between UNOmaha and AESM. UNOmaha has had a relationship with AESM in many academic areas lasting over 10 years. Also UNOmaha in 1996 was instrumental in developing the Moldovan American Center for Private Initiative (MACPI). The MACPI functions as a small business development center and was founded in 1993 under the auspices of UNOmaha and AESM with funding from Eurasia Foundation. The objectives of the MACPI are to:

- $\quad$ Contribute to creation of new enterprises

- $\quad$ Improve competitiveness of existing enterprises

- $\quad$ Promote interest in private enterprises

- $\quad$ Provide consulting and training 
The Center has provided significant consulting to many enterprises in Moldova, and it is now a self-supporting organization.

The purpose of UNOmaha and AESM's relationship was to create cooperation between the two universities in the areas of accounting and auditing that will aid in the economic growth and development of Moldova. This will be accomplished by focusing on education, training, exchange of faculty, and materials.

AESM is the premier business university in Moldova and was established in 1991. AESM currently has an enrollment of over 9,000 students and a faculty of 700. AESM consists of the departments of Accounting, Economic Statistics and Information, Finance, International Economic Relations, Management, and Marketing.

The Accounting Department at AESM has an enrollment of over 1,900 students and the enrollment is significantly increasing. In the fall of 2000, 580 new students were admitted into the program and accounting is the fastest growing program at the University.

The cooperation of the two universities will concentrate on the areas of deficiency in the AESM educational system. The most significant deficiency is the limited supply of materials. No textbooks or related materials are available because of the limited number of Romanian language accounting textbooks. This obliviously creates significant problems in the methods of education that are available to the professors.

Another area of deficiency is inadequate teaching approaches caused by the lack of textbooks. As with many central and eastern European universities, the traditional lecture method is used primarily. By helping the AESM faculty to develop new teaching approaches along with additional materials, increased learning can take place by the students through the use of more interactive teaching approaches.

Also the lack of materials, which require the dictating of problem material, creates significant deficiencies in learning. Since students have no textbook or handout materials, the lecture notes and problem materials must be dictated by the professors during class time. This causes students to spend too much time in the classroom in ways that are unproductive to learning.

As a way to help facilitate new teaching approaches, faculty exchanges will take place between AESM and UNOmaha faculty. UNOmaha faculty will assist in training AESM professors in technical accounting issues, teaching methods, and curriculum. While at UNOmaha AESM faculty will attend UNOmaha accounting classes to observe their teaching methods. Then when the AESM faculty return, they will be able to incorporate these methods into their style of teaching. In addition, training will cover the areas of creating syllabi, developing interactions with students during class time, and the use of technology in the classroom to enhance learning.

Also while AESM faculty are at UNOmaha, they will be able to develop course materials to use in their own classrooms and have those materials reviewed by UNOmaha faculty. Then when UNOmaha faculty travel to AESM they will provide lectures to AESM students on new developments in accounting and auditing and they will be able to observe AESM faculty in the classroom and offer feedback on their teaching methods.

MARP achieved significant success in accounting practice and accounting education reforms. In many areas MARP created self-sustaining activities that will have a very positive long-term effect in Moldova. The funding for the MARP activities expired in 2001. Even though significant achievements were attained, the process of accounting reform in Moldova is not finished.

\section{The Next Step}

The Financial Management Training and Advisory Activity (FMTAA) project announced its opening in Chisinau in September 2001. The FMTAA Project as a successor of MARP continues to build on the progress of financial reforms started by MARP. Much of the MARP staff continues with the new project. This project was 
initiated upon common agreement between the Governments of the Republic of Moldova and the United States of America. It is again funded by the USAID and being implemented by the East-West Management Institute.

The objective of the new FMTAA project is to consolidate fiscal and financial sector reform to support private enterprise growth. The activities of the FMTAA project will focus on:

- Providing training and advisory services in financial and managerial accounting, financial management, audit, and accounting software

- Supporting the continuing development of the Association of Professional Accountants and Auditors of the Republic of Moldova (ACAP)

- Assisting the Academy of Economic Studies of Moldova in accounting and auditing curriculum reform, improving teaching skills, and strengthening the partnership between the accounting departments of AESM and the UNOmaha;

- $\quad$ Promoting accounting information technology

\section{Conclusion}

Significant economic reforms have been achieved and are continuing to take place in Moldova. Privatization is moving ahead, but accounting reform is required to help private enterprises achieve success. MARP and its successor FMTAA have spearheaded accounting reform projects in the Republic of Moldova and they have followed a three-prong approach to achieve success. Firstly, they worked with the Moldovan government to achieve adoption of new accounting and auditing standards. Secondly, ACAP was developed to provide a self-sustaining professional accounting association to promote accounting and auditing throughout Moldova. Thirdly, they are working with Moldovan universities to create accounting curriculum and accounting education reforms that will ensure a continuing supply of well-trained, technically knowledgeable accountants for the future. The economic and accounting reforms that have taken place in Moldova will provide a foundation for Moldova to move ahead in the future.

\section{References}

1. $\quad$ Enthoven, Adolf J.H., 1999. “Russia’s Accounting Moves West,” Strategic Finance, July, 32-37. 
Table 1

Five-Year Curriculum Course Sequence

\section{First Year}

General Education 1

General Education 2

General Education 3

Math - Calculus

Macroeconomics

Total 480 hours

\section{Second Year}

Microeconomics

Statistics

Principles of Accounting

Management

General Education

$$
\text { Total } 480 \text { hours }
$$

\section{Third Year}

Intermediate Accounting

Business Law

Marketing

International Management

Information Systems

Electives

Total 480 hours

\section{Fourth Year}

Managerial Accounting

Cost Accounting

Finance

Production Operations Mgt

Acct Information Systems

Governmental Accounting

Technical Writing

International Currency

Electives

Total 480 hours

\section{Fifth Year}

Auditing

Tax Accounting

Gen Ed-Multicultural, Global Issues

Advanced Accounting

Electives

Total 480 hours
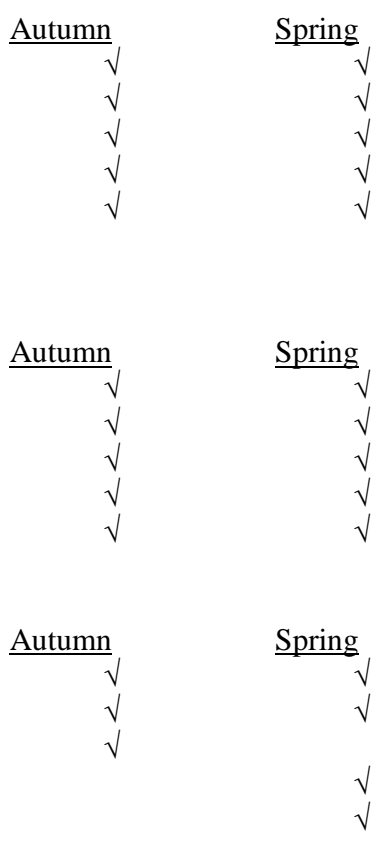

144hours
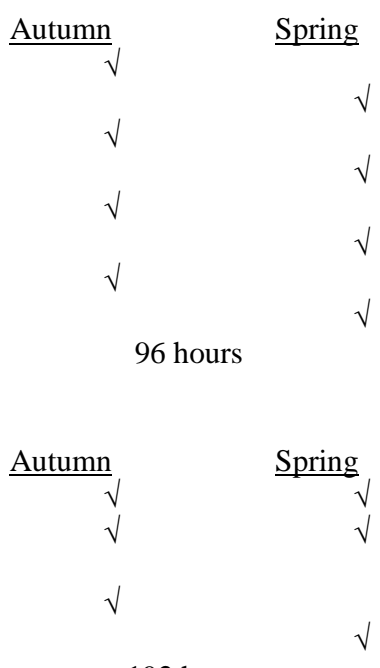

192 hours 